IIUM

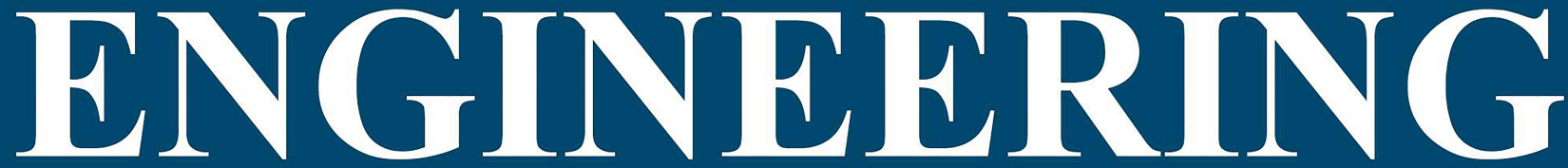

JOURNAL

Volume 22

Number 2

July 2021

INTERNATIONAL ISLAMIC UNIVERSITY MALAYSIA

ISSN: 1511-788X E-ISSN: 2289-7860 http://journals.iium.edu.my/ejournal 


\section{IIUM ENGINEERING JOURNAL}

\section{CHIEF EDITOR}

Ahmad Faris Ismail, IIUM, Malaysia

TECHNICAL EDITOR

Sany Izan Ihsan, IIUM, Malaysia

EXECUTIVE EDITOR

AHM Zahirul Alam, IIUM, Malaysia

ASSOCIATE EDITOR

Nor Farahidah Za'bah, IIUM, Malaysia

LANGUAGE EDITOR

Lynn Mason, Malaysia

\section{COPY EDITOR}

Hamzah Mohd. Salleh, IIUM, Malaysia

\section{MALAY TRANSLATOR}

Nurul Arfah Che Mustapha, IIUM, Malaysia

\section{EDITORIAL BOARD MEMBERS}

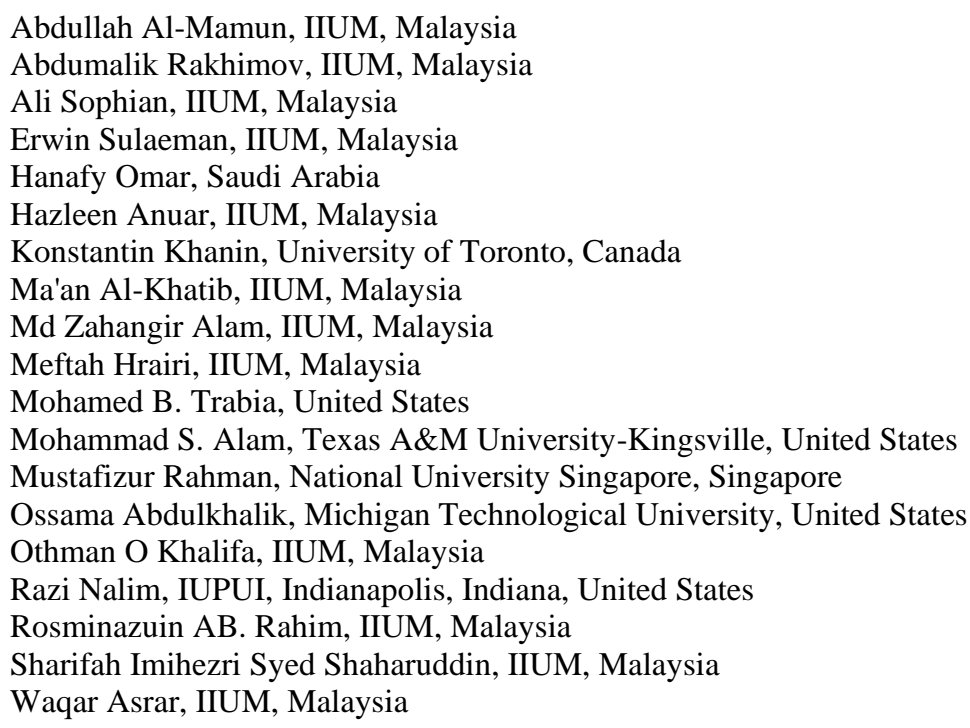

\section{AIMS \& SCOPE OF IIUMENGINEERING JOURNAL}

The IIUM Engineering Journal, published biannually (January and July), is a carefully refereed international publication of International Islamic University Malaysia (IIUM). Contributions of high technical merit within the span of engineering disciplines; covering the main areas of engineering: Electrical and Computer Engineering; Mechanical and Manufacturing Engineering; Automation and Mechatronics Engineering; Material and Chemical Engineering; Environmental and Civil Engineering; Biotechnology and Bioengineering; Engineering Mathematics and Physics; and Computer Science and Information Technology are considered for publication in this journal. Contributions from other areas of Engineering and Applied Science are also welcomed. The IIUM Engineering Journal publishes contributions under Regular papers and Invited review papers. It also welcomes contributions that address solutions to the specific challenges of the developing world and address science and technology issues from an Islamic and multidisciplinary perspective.

\section{REFEREES' NETWORK}

All papers submitted to IIUM Engineering Journal will be subjected to a rigorous reviewing process through a worldwide network of specialized and competent referees. Each accepted paper should have at least two positive referees' assessments.

\section{SUBMISSION OF A MANUSCRIPT}

A manuscript should be submitted online to the IIUM-Engineering Journal website at http://journals.iium.edu.my/ejournal. Further correspondence on the status of the paper could be done through the journal website. 


\title{
INTERNATIONAL ADVISORY COMMITTEE
}

\author{
A. Anwar, United States \\ Abdul Latif Bin Ahmad, Malaysia \\ Farzad Ismail, USM, Pulau Pinang, Malaysia \\ Hanafy Omar, Saudi Arabia \\ Hany Ammar, United States \\ Idris Mohammed Bugaje, Nigeria \\ K.B. Ramachandran, India \\ Kunzu Abdella, Canada \\ Luis Le Moyne, ISAT, University of Burgundy, France \\ M Mujtaba, United Kingdom \\ Mohamed AI-Rubei, Ireland \\ Mohamed B Trabia, United States \\ Syed Kamrul Islam, United States \\ Tibor Czigany, Budapest University of Technology and Economics, Hungary \\ Yiu-Wing Mai, The University of Sydney, Australia.
}

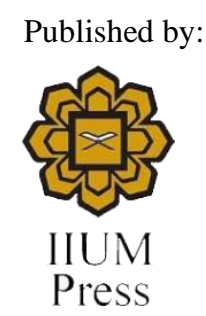

IIUM Press,

International Islamic University Malaysia

Jalan Gombak, 53100 Kuala Lumpur, Malaysia

Phone (+603) 6421-5014, Fax: (+603) 6421-6298

Whilst every effort is made by the publisher and editorial board to see that no inaccurate or misleading data, opinion or statement appear in this journal, they wish to make it clear that the data and opinions appearing in the articles and advertisement herein are the responsibility of the contributor or advertiser concerned. Accordingly, the publisher and the editorial committee accept no liability whatsoever for the consequence of any such inaccurate or misleading data, opinion or statement.

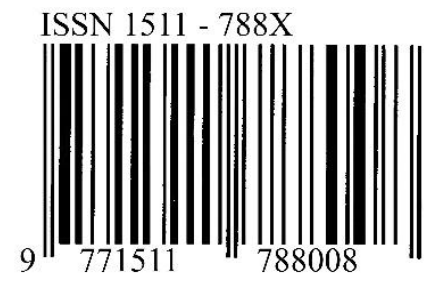

IIUM Engineering Journal

ISSN: 1511-788X E-ISSN: 2289-7860 


\title{
IIUM ENGINEERING JOURNAL
}

\author{
Volume 22, Issue 2, July 2021 \\ https:/doi.org/10.31436/iiumej.v22i2 \\ Table of Contents
}

EDITORIAL

\section{CHEMICAL AND BIOTECHNOLOGY ENGINEERING}

1563: Acoustic Wave Propagation in High Scale Impedance Mismatch Mediums. 1

Md Rabiul Awal, Muzammil Jusoh, Muhammad Syarifuddin Yahya, Nurul Adilah Abdu Latiff,

Salisa Abdul Rahman, Ahmad Nazri Dagang, Hidayatul Aini Zakaria and Shakir Saat

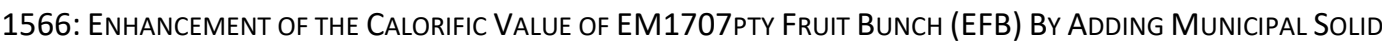

WASTE AS SOLID FUEL IN GASIFICATION PROCESS

Amadou Dioulde Donghol Diallo, Ma'an Fahmi Rashid Alkhatib, Md. Zahangir alam and Maizirwan Mel

1608: MiCROWAVE IRRADIATION OPTIMIZATION FOR EFFICIENT LIGNIN REMOVAL FROM COCOA SHELL

WASTE USING ALKALI 21

Farah Hafidzah Ahmad, Nurhamizah Ibrahim, Mohd Sabri Mahmud, Waleed Ali, Mohd Bijarimi Mat Piah, Suriyati Salleh and Said Nurdin

1682: AdSORPTION OF METHYLENE BLUE ONTO ACTIVATED CARBON DEVELOPED FROM BAOBAB FRUIT SHELL BY CHEMICAL

ACTIVATION: KINETIC EQUILIBRIUM STUDIES

Radhia Nedjai, Ma'an Fahmi Rashid Alkhatib, Md Zahangir Alam and Nassereldeen Ahmed Kabbashi

1687: CYTOTOXICITY EFFECT OF IONIC LIQUID-GRAVIOLA FRUIT (ANNONA MURICATA) EXTRACT

TO HUMAN COLON CANCER (HT29) CELl LINES

Djabir Daddiouaissa, Azura Amid, Nassereldeen Ahmed Kabbashi, Ahmed Adam Mohammed Elnour and Mohamad Adika Khairy Bin Mohd Shaifudin Epandy

\section{CIVIL AND ENVIRONMENTAL ENGINEERING}

1589: Influence of Different PerCentage BoIler Ash-BASEd Geopolymer In LATERITE SOIL. 67 Atiqah Najwa Zainuddin, Mazidah Mukri, Diana Che Lat, Roslizayati Rosli and Noor Hidayu Abdul Rani

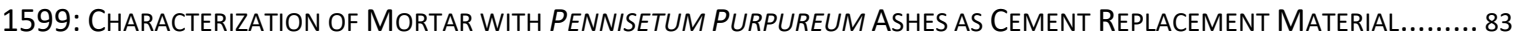
Mohd Haziman Wan Ibrahim, Mohammed Yahya Al-Fasih, Nik Nadia Amira Nik Pa, Ramadhansyah Putra Jaya and Muhammad Ikhsan Setiawan

\section{ELECTRICAL, COMPUTER AND COMMUNICATIONS ENGINEERING}

1464: WSN-BASED MONITORING SYSTEMS FOR SOLAR POWER STATIONS OF THE TELECOMMUNICATION OBJECTS

Khujamatov Khalimjon Ergashevich, Khasanov Doston Turayevich, Fayzullaev Bayram Artikbayevich and Reypnazarov Ernazar Nurjamiyevich

1541: DeVeloping a PARAllel CLASSIFIER For Mining In BIg DATA SetS.

Ahad Shamseen, Morteza Mohammadi Zanjireh, Mahdi Bahaghighat and Qin Xin

1559: Influence of Light AbSorption Profile ON the Performance of ORganic Photovoltaics.

Abdul Halim Ikram Mohamed and Mohd Lukman Inche Ibrahim

1565: StUdy of EfFECTIVE OMNI-DIRECTIONAL VeRTICAL AXIS WIND TURBINE FOR LOW SPEEd REGIONS

Alisher Bekmurdovich Safarov And Rasul Akif-Ogli Mamedov

1597: Double Threshold SpeCtrum Sensing With Optimization of SAMPles In Cognitive Radio NetWorks

Chilakala Sudhamani

1612: An InVestigation of the Sensitivity of Polymer-CoAted Surface Acoustic WaVe-BaSed Gas

SENSORS IN THE DETECTION OF VolATILE ORGANIC COMPOUNDS

Aliza Aini Md Ralib and Amirah Syahirah Syamsil Omar

1613: A ReVIeW of Flow Conflicts ANd Solutions in Software Defined Networks (SDN).....

Mutaz Hamed Hussien Khairi, Sharifah Hafizah Syed Ariffin, Nurul Muaazah. Abdul Latiff,

Kamaludin Mohamed Yusuf and Mohamed Khalafalla Hassan

1618: EXPerimental Verification of Three Mode Controller for Home APPlanCe Using Wireless TeChNOLOGY.. 188 Maswoodhur Rahman Abdul Wahidh and Muruganandam Masilamani

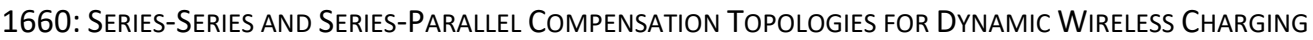

Muhammad Amirul Asyraf Roslan, Nadia Nazieha Nanda and Siti Hajar Yusoff 
1662: Online News Classification Using Machine Learning TeChNiques.

Jeelani Ahmed and Muqeem Ahmed

1692: MACHINE-LEARNING-BASED EVALUATION OF CORROSION UNDER INSULATION IN FERROMAGNETIC STRUCTURES

Ali Sophian, Faris Nafiah, Teddy Surya Gunawan, Nur Amalina Mohd Yusof and Ali Al-Kelabi

1752: CLASSIFICATION OF CHEST RADIOGRAPHS USING NOVEL ANOMALOUS SALIENCY MAP AND DEEP

CONVOLUTIONAL NEURAL NETWORK....

Mohd Adli Md Ali, Mohd Radhwan Abidin, Nik Arsyad Nik Muhamad Affendi, Hafidzul Abdullah,

Daaniyal Reesha Rosman, Nu'man Badrud'din, Faiz Kemi and Farid Hayati

\section{MATERIALS AND MANUFACTURING ENGINEERING}

1507: SURfaCe RoughnesS PREDICTION IN TURNINg Process by APPLYING COMPUTER VISION Method 249

Omer Wathiq Taha and Osamah Fadhil Abdulateef

1547: The Effect of Lateral Lifting Tasks on Hand Grip And Pinch Strength Measurements

Joe Yee Tan, Azrul Azwan Bin Abdul Rahman, Nadiah Binti Ahmad and Arfauz Bin A. Rahman

1640: Effect of Machining Parameters on Surface Roughness, PoWer Consumption, And Material

Removal Rate Of Aluminium 6065-Si-MwCnt Metal Matrix Composite In TuRning Operations

Savina Jaddinagadhe Puttaswamy and Raghavendra Bommanahalli Venkatagiriyappa

1673: POTENTIAL OF FABRICATION OF DURIAN SKIN FIBER BIOCOMPOSITES FOR FOOD PACKAGING APPLICATION

THROUGH THE ELECTRICITY IMPACT ANALYSIS

Hazleen Anuar, Siti Munirah Salimah Abd Rashid, Nurfarahin Mohd Nordin, Fathilah Ali,

Yose Fachmi Buys, Sabu Thomas and Nur Aimi Mohd Nasir and Syazeven Effatin Azma Mohd Asri

1715: MODEL ANALYZING FOR REUSING GOLD WIRE CAPILLARY IN THE GOLD WIRE BONDING PROCESS

Chatpon Phimpha and Sombat Sindhuchao

1747: Mechanical Properties, Water Absorption, and Failure Analyses of Kenaf Fiber Reinforced

EPOXY MATRIX COMPOSITES

Ikhwan Yusuff, Norshahida Sarifuddin Siti Norbahiyah and Afifah Mohd Ali

1768: Effect of Magnetic Field on The Physical and Chemical Properties of Flowing Lubricating

COOLING LIQUIDS USEDIN THE MANUfACTURING PROCESS

Erkin Odilov, Umidjon Mardonov, Khusniddin Abdirakhmonov, Abdugani Eshkulov and Behzod Rakhmatov

\section{MECHANICAL AND AEROSPACE ENGINEERING}

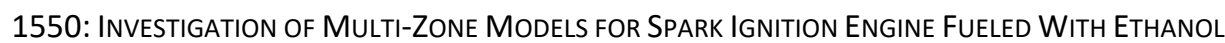
.339

Olatunde Bilikis Olanrewaju, Dare Adebukola Ademola, Ismail Olawale Saheed, Shote Adeola Suhud, Alamu Oguntola Jelili and Sulaiman Adedoyin Musediq

1707: Analytical and Numerical Thermal Analysis on Friction StiR Welding Using Polygonal ToOl Pin .352

Stephen Leon Joseph Leon, Alfred Franklin Varghese, Joseph Michel and Gopinath Gunasekaran

\section{MECHATRONICS AND AUTOMATION ENGINEERING}

1691: Multi-Objective Optimization of Snake Robot in SeRPentine Locomotion .364 Marwan Badran, Md Raisuddin Khan, Siti Fauziah Toha and Zulkifli Zainal Abidin 1706: MOdELLING A 1-DOF FINGER EXTENSOR MACHINE FOR HAND REHABILITATION. 384 Ifrah Shahdad, Norsinnira Zainul Abidin and Ahmad Jazlan 